\title{
Eksplorasi epistemological dan didactical obstacle serta hypothetical learning trajectory pada pembelajaran konsep jarak
}

\author{
Redi Hermanto, Satya Santika \\ Program Studi Pendidikan Matematika FKIP Universitas Siliwangi \\ e-mail: redihermanto@unsil.ac.id
}

\begin{abstract}
ABSTRAK
Geometri merupakan salah satu materi yang sangat penting dalam pembelajaran matematika. Hanya saja, pada kenyataannya tidak sedikit siswa yang mengalami kesulitan dalam memahai konsep geometri yang diajarkan. Salah satu materi geometri yang dianggap sulit adalah materi dimensi tiga yang diberikan kepada siswa kelas $X$ SMA khususnya mengenai konsep jarak. Penelitian ini dilaksanakan di salah satu SMA di Kota Tasikmalaya dengan subjek penelitian sebanyak 32 siswa kelas X. Berdasarkan hasil pengamatan peneliti tentang learning obstacle yang dialami siswa ditinjau dari epistemological dan didactical obestacle, bahwa hambatan belajar siswa dalam materi dimensi tiga terletak pada (1) menentukan letak hasil proyeksi suatu titik terhadap garis, (2) menentukan letak hasil proyeksi suatu titik terhadap bidang, dan (3) membuat dan mengenali bentuk sebuah bidang yang memuat titik dan memuat ruas garis pada bidang tersebut (yang memuat hasil proyeksi titik). Untuk meminimalisis learning obstacle tersebut, peneliti menyusun Hypothetical Learning Trajectory (HLT) agar siswa mampu memahami konsep jarak pada dimensi tiga secara lebih optimal. HLT pada pembelajaran materi jarak antara titik dengan garis meliputi: concept by definition, projection, making a plane, dan distance, sedangkan untuk HLT pada pembelajaran materi jarak antara titik dengan bidang meliputi: concept by definition, finding a segment, projection, making a plane, dan distance.
\end{abstract}

Kata Kunci: epistemological \& didactical obstacle, hypothetical learning trajectory, jarak pada bangun ruang

\section{PENDAHULUAN}

Geometri merupakan salah satu materi yang sangat penting dalam pembelajaran matematika. Ide-ide geometri digunakan untuk mempresentasikan dan memecahkan masalah pada materi matematika lainnya dan situasi dunia nyata (NCTM 2000, P.41). Pada dasarnya siswa sudah mengenal geometri dalam kehidupan sehari-hari seperti garis, bangun datar dan bangun ruang. Sekilas materi geometri dalam pembelajaran matematika terlihat mudah, siswa hanya menggambar dan menghitung apa yang dicari. Namun, pada kenyataannya tidak sedikit siswa yang mengalami kesulitan dalam memahai konsep geometri yang diajarkan. Penelitian yang dilakukan beberapa ahli menunjukkan bahwa siswa pada tingkat SMA pun memiliki pengetahuan atau pengalaman yang sedikit sekali mengenai sifat-sifat bangun ruang geometri (Jiang, 2008). Kesulitan materi geometri dimensi tiga ini tidak hanya dialami para siswa saja tetapi juga guru dalam mengajarkannya.

Pembelajaran geometri di SMA kelas X sejak Kurikulum tahun 1994 suplemen 1999, Kurikulum 2004 (Kurikulum Berbasis Kompetensi (KBK)) dan Kurikulum tahun 2006 (Kurikulum Tingkat Satuan Pendidikan (KTSP)) ditempatkan paling akhir di tahun ajaran. Sedangkan pada kurikulum tahun 2013 materi geometri dimensi tiga pada Bab 9 sebagai materi pengayaan. Melihat paradigma ini, seolah-olah meteri geometri kurang mendapatkan perhatian yang serius. Geometri juga tidak dianggap sebagai sesuatu yang penting karena penyajiannya hanya sebagian kecil saja dan konsep-konsep yang disajikan lebih berorientasi pada konsep yang mudah-mudah saja.

Berikut ini akan di uraikan garis besar materi geometri yang dipelajari siswa mulai dari 
sekolah dasar sampai sekolah menengah, serta implikasi yang jelas dan penting dari materi geometri dengan materi-materi lain pada kurikulum matematika di Indonesia: (1) Pengukuran (Sekolah Dasar): Pengukuran dan geometri sangat sejalan terutama dalam menentukan rumus keliling dan luas bangun datar dan serta menghitung volume suatu bangun ruang; (2) Pecahan (Sekolah Dasar): Materi pecahan memiliki keterkaitan dengan geometri, karena di Sekolah Dasar siswa mempelajari pecahan melalui bagian-bagian dari bentuk. Hubungan ini mungkin lebih pedagogis daripada matematis; (3) Bilangan Bulat (Sekolah Dasar): Bidang koordinat menyediakan ketertarikan karena baik angka positif maupun angka negatif digunakan dalam penjabaran posisi dalam bidang dan ruang; (4) Segitiga dan Segiempat (Kelas VII): Pada materi ini dijelaskan mengenai unsur-unsur beserta sifat-sifat dari segitiga dan segiempat, menghitung luas daerah serta keliling bangun segitiga dan segiempat; (5) Lingkaran (Kelas VIII): Pada materi ini dijelaskan mengenai unsur-unsur lingkaran, luas dan keliling lingkaran, hubungan sudut pusat dan sudut keliling pada lingkaran yang menghadap busur yang sama. Selain itu, di bahas juga bagaimana menentukan garis singgung lingkaran dan sifat-sifat di dalamnya. Pada kelas XI dibahas mengenai bagaimana menentukan persamaan garis singgung lingkaran serta aplikasinya; (6) Bangun ruang sisi datar (Kelas VIII): Materi ini membahas tentang volume serta luas permukaan dari kubus, balok, limas, dan prisma serta aplikasinya dalam kehidupan seharihari; (7) Aljabar: Pengembangan grafik koordinat memberikan sebuah pandangan analitis akan konsep gradien, hubungan garis-garis sejajar dan tegak lurus. Hubungan Pythagoras membawa kita kepada pendekatan aljabar terhadap jarak antar titik-titik sudut pada sebuah bidang. Transformasi bentuk-bentuk (translasi, rotasi, refleksi, dilatasi) dapat dijabarkan dalam istilah koordinat yang memungkinkan manipulasi dari bentuk. Dunia animasi komputer secara keseluruhan didasarkan pada kombinasi antara aljabar dan geometri (Van de Walle, 2008); (8) Bangun ruang sisi lengkung (Kelas IX): Materi ini membahas tentang volume serta luas permukaan dari tabung, kerucut, dan bola serta aplikasinya dalam kehidupan sehari-hari; (9) Kesebangunan (Kelas IX): Materi kesebangunan membahas sifatsifat dua bangun yang sebangun dan kongruen. Konsep kesebangunan dapat diaplikasikan lebih jauh pada desain dan arsitektur; dan (10)Dimensi Tiga (Kelas X): Materi ini membahas mengenai kedudukan titik, garis, dan bidang, jarak antar titik, garis, dan bidang serta sudut yang dibentuk oleh dua garis, garis dan bidang, serta bidang dan bidang. Di samping itu, dibahas juga mengenai aplikasi konsep jarak dan sudut secara lebih analitis.

Berdasarkan uraian di atas, ternyata konsep geometri pada kurikulum kita tidak bisa dipandang sebelah mata dan harus mendapatkan perhatian yang lebih serius. Begitu banyak materi yang berhubungan dengan geometri serta implikasi materi geometri pada materi-materi lain. Sebenarnya masih banyak implikasi geometri pada materi-materi lain pada tingkatan yang lebih tinggi, di antaranya sistem persamaan linear, fungsi kuadrat, diferensial dan integral, analisis vektor, aljabar linear, dan masih banyak lagi yang lainnya.

Melihat implikasi konsep geometri pada materi-materi lain dalam matematika maupun dengan materi di luar matematika, ternyata materi geometri ini sangat penting untuk dipelajari oleh siswa. Menurut Van de Walle (2008) menyatakan bahwa geometri perlu dipelajari karena alasan sebagai berikut: (1) Geometri membantu memiliki keyakinan yang utuh tentang dunianya. (2) Eksplorasi dalam geometri dapat membantu mengembangkan kemampuan pemecahan masalah. (3) Geometri memainkan peran utama dalam bidang lainnya. (4) Geometri digunakan oleh banyak orang dalam bidang kehidupan sehari-hari. (5) Geometri penuh teka-teki dan menyenangkan.

Apabila kita perhatikan materi geometri yang selama ini disajikan oleh guru, selalu mengacu pada buku teks, di mana materinya disesuaikan dengan kurikulum yang sedang berlaku. Tapi sayangnya, kurikulum geometri sekolah, hingga saat ini, hanya memasukkan 
sangat sedikit jenis-jenis pengalaman yang benar. Kurikulum geometri sekolah dasar dan menengah terlalu banyak memasukkan pengalaman-pengalaman tingkat-rendah di mana para pembelajar hanya diminta untuk mempelajari nama-nama bangun dan nama-nama dari objek-objek geometris lainnya. Kemudian di sekolah menengah atas, para pembelajar diharapkan untuk mempelajari penalaran geometris ketika berhadapan dengan buktibukti. Kurikulum sekolah dasar yang khas menjaga anak-anak tetap berada pada tingkat perkembangan yang rendah, dan kemudian kurikulum sekolah menengah atas secara tidak masuk akal mengharapkan para siswa untuk melompat ke tingkatan perkembangan yang tinggi. Bagi kebanyakan siswa lompatan ini mustahil dilakukan, dan perkembangan pemikiran geometris mereka terhalangi (Wahyudin, 2013). Oleh karena itu, dirasa sangat perlu menyusun bahan ajar yang disusun berdasarkan penelitian terhadap learning obstacle (hambatan belajar) siswa dalam suat materi pembelajaran matematika. Terutama dalam menghadapi materi geometri khususnya dimensi tiga di kelas X Sekolah Menengah Atas (SMA), siswa terkadang mengalami hambatan dalam menyelesaikan masalah yang dihadapi.

Learning obstacle merupakan hambatan atau kesulitan-kesulitan yang terjadi dalam proses pembelajaran. Kesulitan yang dihadapi oleh siswa ketika belajar tidak selalu sama, hal ini terjadi karena siswa mempunyai hambatan yang berbeda-beda dalam pembelajarannya. Dengan kata lain, hambatan atau kesulitan belajar ini tidak dapat dihindari karena merupakan bagian dari setiap proses pembelajaran. Brousseau (1997) mengemukakan tiga jenis kesulitan atau hambatan belajar (learning obstacle) yaitu ontogenic, epistemological, dan didactical obstacle yang dapat terjadi dalam proses belajar. Ontogenic obstacle adalah jenis kesulitan berkaitan dengan kesiapan anak dalam belajar. Epistemological obstacle merupakan jenis kesulitan belajar ini lebih disebabkan keterbatasan konteks yang digunakan pada saat pertamakali suatu konsep dipelajari (Duroux dalam Brusseau, 1997). Didactical obstacle merupakan kesulitan belajar yang diakibatkan oleh keadaan desain didaktis yang digunakan atau intervensi didaktis guru (Suryadi, 2015). Pada penelitian ini diungkap learning obstacle, khususnya yang bersifat epistemologis dan didaktis pada materi jarak pada bangun ruang.

Untuk mencapai sebuah tujuan pembelajaran yang ditetapkan guru, setiap siswa memiliki alur belajar (learning trajectory) sendiri yang bersifat unik. Perbedaan pengalaman belajar serta ragam obyek mental yang terbentuk dari setiap pengalaman tersebut memberikan dampak besar terhadap variasi alur belajar siswa. Agar guru mampu memfasilitasi ragam alur belajar yang berkembang pada saat pembelajaran, guru harus mampu memprediksi berbagai kemungkinan respon siswa sebagai akibat situasi didaktik yang dikembangkan, sehingga alur belajar dugaan (Hypothetical Learning Trajectory atau HLT) dapat menjadi acuan utama proses fasilitasi dalam bentuk intervensi didaktis maupun pedagogis. Sebuah HLT dikembangkan berdasarkan tujuan yang ingin dicapai, serta tahapan belajar berupa rangkaian situasi didaktis saling berkesinambungan menuju pencapaian tujuan (Clements \& Sarama, 2004).

Pentingnnya $H L T$ bisa dianalogikan dengan perencanaan rute perjalanan, jika kita memahami rute-rute dalam perjalanan untuk menuju tujuan yang ingin kita lalui, maka kita bisa memilih rute yang baik untuk digunakannya. Selain itu, kita juga bisa menyelesaikan permasalahan yang kita hadapi dalam perjalanan jika kita paham rute tersebut. Ketika mendesain kegiatan pembelajaran, guru sebaiknya menyusun hipotesis tindakan atau reaksi siswa pada setiap tahap pembelajaran. Pada tahap awal perencanaan pembelajaran, hipotesis tersebut didasarkan pada perkiraan pengetahuan awal (pre knowledge) yang sudah dimiliki siswa serta berdasarkan pengalaman-pengalaman atau praktik pembelajaran topik tersebut pada tahun sebelumnya. 
Pada kesempatan ini peneliti akan mencoba mengeksplor beberapa hambatan belajar yang dihadapi siswa, khususnya dalam mempelajari konsep geometri dimensi tiga. Ruang lingkup materi dimensi tiga yang akan di bahas di sini mencakup konsep jarak antara dua titik, jarak titik terhadap garis, dan jarak titik terhadap bidang. Peneliti akan mencoba mengkaji hambatan belajar siswa dilihat dari aspek epistemological obstacle dan didactical obstacle. Setelah peneliti mengkaji learning obstacle siswa dalam pembelajaran materi dimensi tiga, peneliti berharap kajian ini akan menjadi dasar bagi peneliti untuk menyusun HLT yang menitik beratkan pada aktivitas berpikir siswa dalam mengonstruksi suatu konsep geometri sehingga pembelajaran geometri ini mudah dipahami oleh siswa.

Berdasarkan uraian yang telah dikemukakan sebelumnya, maka tujuan dari penelitian ini adalah untuk mengetehui leraning obstacle siswa dalam mempelajari materi dimensi tiga khususnya materi jarak pada bangn ruang, ditinjau dari epistemoligical obstacle dan didactical obstacle. Selanjutnya, hasil kajian leraning obstacle tersebut, akan dijadikan acuan peneliti dalam menyusun Hypothetical Learning Trajectory, sehingga diharapkan dapat meminimalisir learning obstacle siswa dalam mempelajari materi geometri.

\section{METODE PENELITIAN}

Berdasarkan tujuan dari penelitian ini, maka metode yang digunakan dalam penelitian ini adalah kualitatif deskriptif. Penelitian kualitatif deskriptif bertujuan untuk menafsirkan fenomena yang terjadi pada siswa (Moleong, 2012). Ruseffendi (2010) penelitian kualitatif deskriptif merupakan penelitian dimana pengumpulan datanya melakukan observasi, wawancara, atau angket mengenai keadaan sekarang dan subjek yang sedang diteliti. Studi kasus menjadi pendekatan yang dipilih untuk penelitian ini. Penelitian ini menggunakan teknik pengumpulan data triangulasi yang terdiri dari observasi, wawancara, dan juga dokumentasi. Subjek penelitian (responden) dalam penelitian ini adalah siswa kelas X di salah satu SMA Negeri di Kota Tasikmalaya yang berumlah 32 orang siswa.

\section{HASIL DAN PEMBAHASAN}

Berdasarkan paparan sebelumnya, bahwa learning obstacle yang akan di kaji dalam tulisan ini terdiri dari epistemological obstacle dan didactical obstacle. Suryadi (2010) menyatakan bahwa hambatan epistemologis merupakan hambatan yang muncul akibat dari pengetahuan seseorang yang terbatas pada konteks tertentu. Jika orang tersebut berhadapan dengan konteks yang berbeda, maka pengetahuan yang dimiliki menjadi tidak dapat digunakan lagi atau dia akan mengalami kesulitan untuk menggunakannya.

Berdasarkan hasil pengamatan peneliti terhadap siswa kelas X salah satu SMA di Kota Tasikmalaya yang terdiri dari 32 siswa, ditemukan beberapa kesulitan siswa mengenai konsep jarak pada bangun ruang. Kesulitan yang paling banyak ditemui di antaranya adalah kesulitan siswa dalam menentukan proyeksi titik terhadap garis atau bidang. Sebagai ilustrasi, peneliti menyajikan kasus berikut ini.

Kasus I: Perhatikan Kubus ABCD.EFGH. Titik P terletak pada ruas garis HB dan FP ? HB. Apakah titik P berada tepat di tengah-tengah HB? Berikan Alasan! 


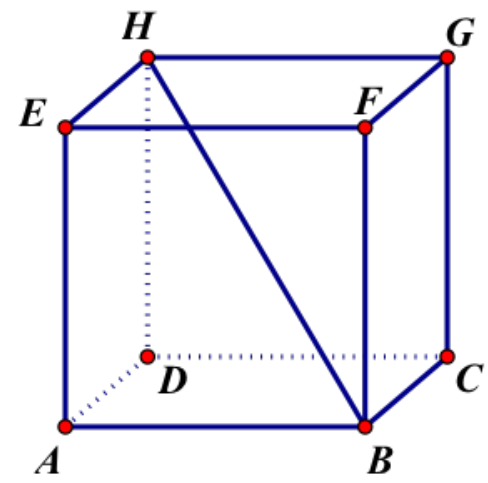

Berdasarkan hasil jawaban dari 32 orang siswa, menunjukkan bahwa semua siswa menjawab "ya". Kebanyakan dari siswa tersebut terpaku pada gambar, mereka terkecoh dengan gambar yang disajikan. Mereka beranggapan bahwa jika FP $\perp$ HB maka titik P akan berada tepat di tengah-tengah $\mathrm{HB}$.

Bahkan sebagian dari mereka tidak memberikan alasan. Berikut ini disajikan beberapa respons siswa terkait dengan permasalahan untuk Kasus I.
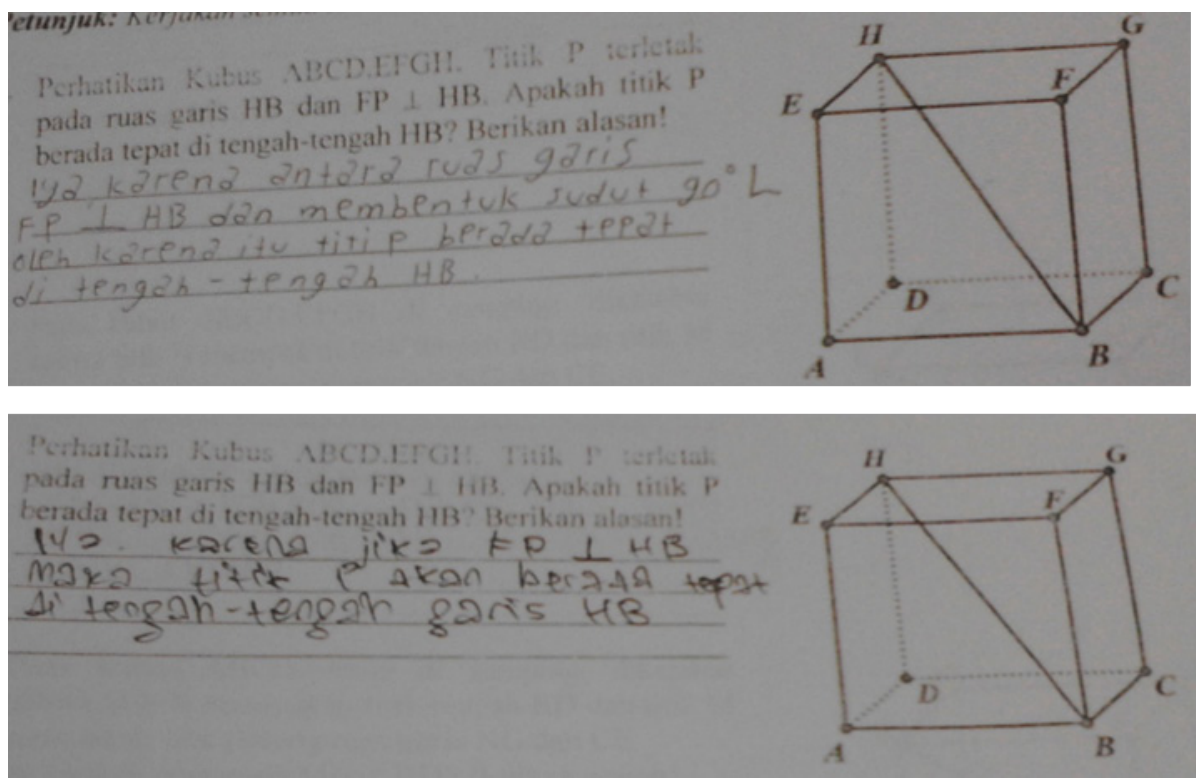

Gambar 1. Hasil Respons Siswa untuk Kasus I

Berdasarkan hasil respons siswa pada Gambar 1. menunjukkan bahwa siswa masih belum memahami proyeksi titik pada garis, dan ini merupakan masalah yang perlu di atasi dan dicari solusinya.

Kasus II: Pada kubus ABCD.EFGH diketahui bahwa titik P merupakan titik tengah HF dan titik Q merupakan titik tengah PF. Apakah proyeksi titik E pada bidang APF terletak pada ruas garis $\mathrm{AQ}$ ? Berikan alasan!

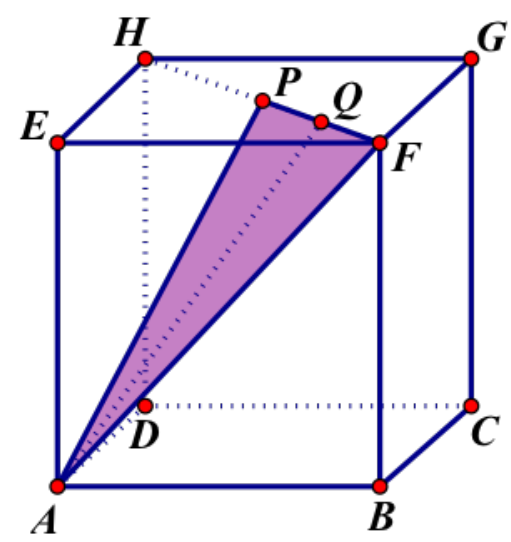

Berdasarkan hasil jawaban dari 32 orang siswa, menunjukkan bahwa sebanyak 8 orang atau $25,0 \%$ siswa menjawab "tidak". Semua siswa yang menjawab "tidak" ini tidak memberikan alasan secara tepat. Mereka seolah-olah hanya mengira bahwa proyeksi titik $E$ pada bidang $A P F$ terletak pada ruas garis $A P$. 
Sedangkan 24 orang siswa atau 75,0\% siswa menjawab "ya". Sebagian besar dari mereka memberikan jawaban "karena proyeksi titik $E$ akan berada pada garis $A Q$ ". Mereka tidak memberikan alasan yang jelas terkait jawaban yang mereka berikan. Namun ada beberapa orang siswa yang memberikan alasan "karena ruas garis $A Q$ memotong bidang $A P F$ dengan luas bidang yang sama”. Berikut ini disajikan beberapa respons siswa terkait Kasus II di atas.
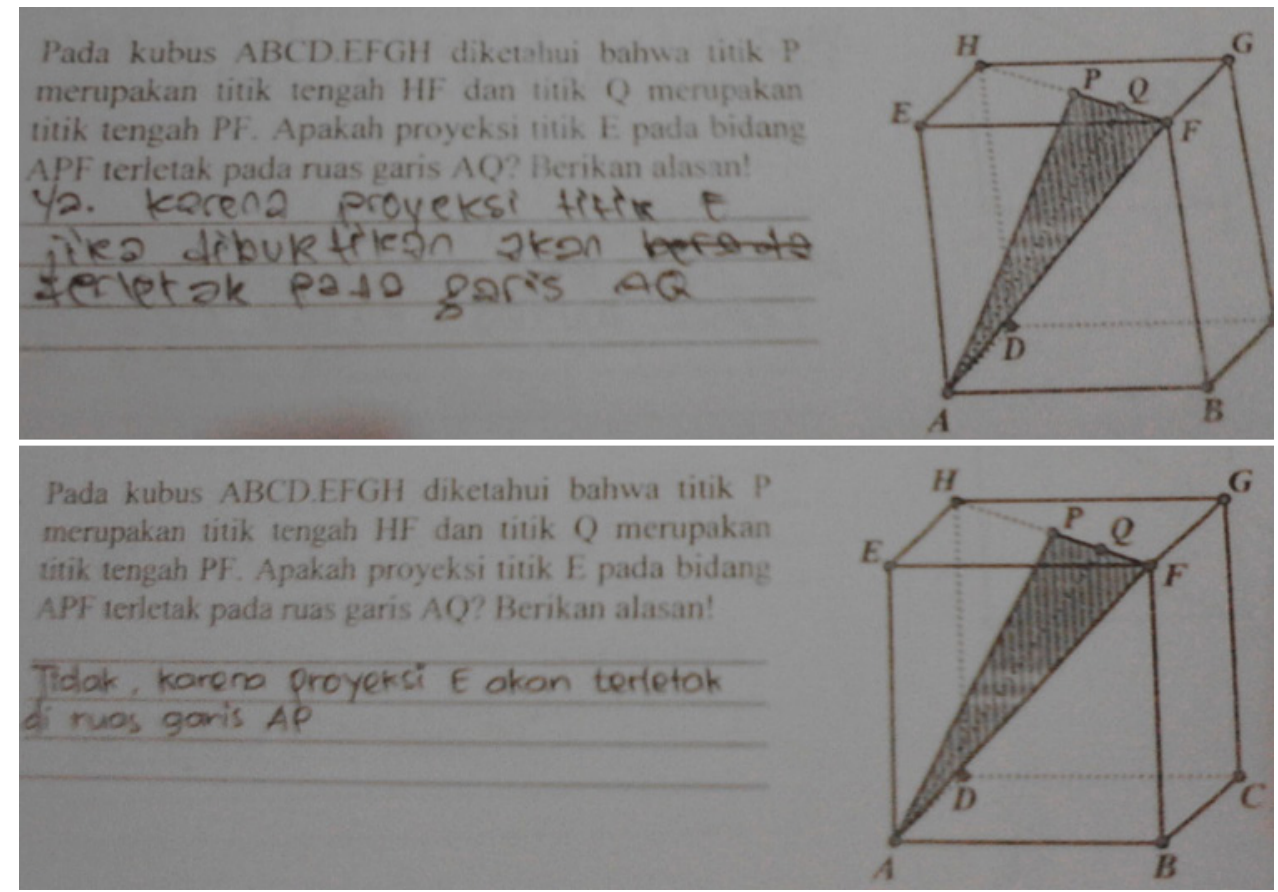

Gambar 2. Hasil Respons Siswa untuk Kasus II

Dari beberapa variasi jawaban siswa tersebut, peneliti menyimpulkan bahwa siswa juga tidak menguasai dengan benar konsep proyeksi sebuah titik terhadap bidang, sehingga mengakibatkan kesalahan konsep geometri. Dengan demikian, perlu ditelusuri secara lebih mendalam, hal-hal apa saja yang menyebabkan lemahnya penguasaan konsep geometri siswa, khususnya mengenai konsep proyeksi titik terhadap garis dan proyeksi titik terhadap bidang. Peneliti memprediksikan secara lebih luas lagi, kemungkinan besar siswa akan mengalami kesulitan untuk memproyeksikan garis pada bidang, karena untuk memproyeksikan garis pada bidang melibatkan konsep-konsep geometri yang lebih kompleks lagi.

Kasus III: Pada kubus ABCD.EFGH di samping, diketahui bahwa titik P, Q dan R masingmasing merupakan titik tengah ruas garis FG, HD, dan AB. Apakah DPQR merupakan segitiga samasisi? Berikan alasan!

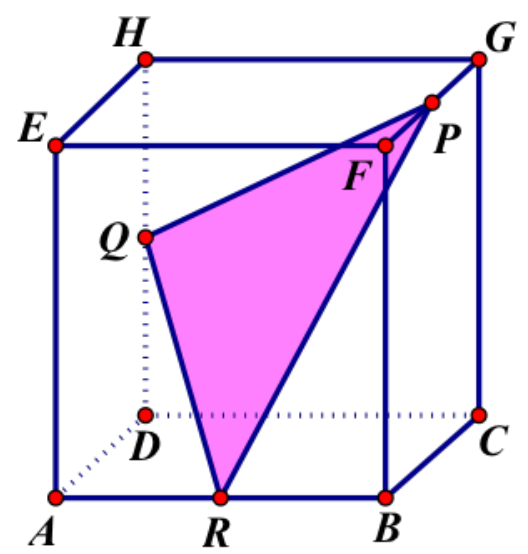

Berdasarkan hasil jawaban dari 32 orang siswa, menunjukkan bahwa sebanyak 31 orang atau 96,88\% siswa menjawab "tidak". Hanya 1 orang siswa saja yang menjawab "tidak tahu". Semua siswa yang menjawab "tidak" ini pada umumnya menyatakan bahwa

segitiga $P Q R$ sebagai segitiga siku-siku di $Q$. Apabila sepintas terlihat dari gambar, memang terlihat bahwa segitiga $P Q R$ merupakan segitiga siku-siku di $Q$, padahal apabila diamati lebih mendalam lagi, ternyata sisi-sisi dari segitiga $P Q R$ memiliki panjang yang sama, atau 
dengan kata lain segitiga $P Q R$ merupakan segitiga samasisi. Berikut ini disajikan respons siswa terkait Kasus III di atas.

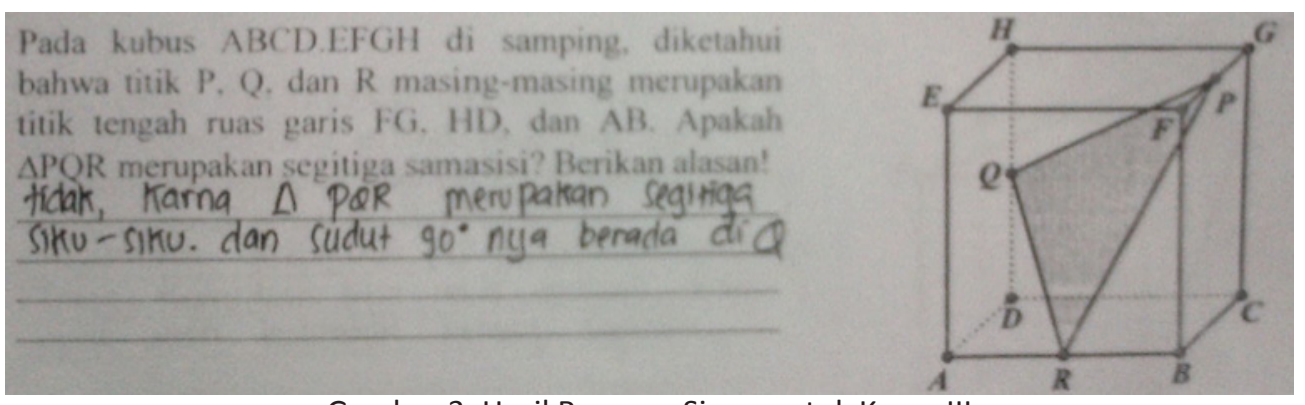

Gambar 3. Hasil Respons Siswa untuk Kasus III

Dari semua jawaban siswa tersebut, peneliti menyimpulkan bahwa kemampuan visualisasi siswa dalam melihat bangun ruang secara menyeluruh belum benar-benar dikuasai dengan baik. Hal ini sangat mempengaruhi siswa pada saat menyelesaikan permasalahanpermasalahan mengenai konsep jarak pada bangun ruang, terutama ketika siswa mentransformasikan bangun datar yang digambarkan pada dimensi tiga ke dalam dimensi dua. Dengan demikian, peneliti perlu menelusuri secara lebih mendalam, hal-hal apa saja yang menyebabkan lemahnya daya visualisasi siswa tersebut dalam memandang bangun ruang.

Berdasarkan fakta-fakta yang peneliti temukan, peneliti mencoba menganalisis buku matematika SMA yang di dalamnya mengkaji materi Dimensi Tiga, terutama tentang konsep jarak pada bangun ruang. Buku-buku yang peneliti analisis ini, pada umumnya digunakan guru sebagai buku teks atau buku pegangan guru dalam mengajarkan konsep-konsep dimensi tiga. Buku-buku yang peneliti analisis juga merupakan buku teks yang digunakan sesuai dengan kurikulum yang sedang berlaku pada saat itu, yaitu mulai dari Kurikulum 1994 Suplemen 1999, Kurikulum 2004 (KBK), Kurikulum 2006 (KTSP) dan Kurikulum 2013. Tujuan peneliti menganalisis buku-buku tersebut adalah untuk memperoleh gambaran tentang alur materi yang diberikan kepada siswa sebagai salah satu kajian mengenai didactical obsacle. Dengan menganalisis keempat buku tersebut, peneliti berharap dapat menemukan hal-hal yang mampu menjawab permasalahan-permasalahan yang berkaitan dengan learning obstacle siswa pada saat mempelajari konsep jarak pada dimensi tiga. Identitas buku yang peneliti analisis adalah sebagai berikut:

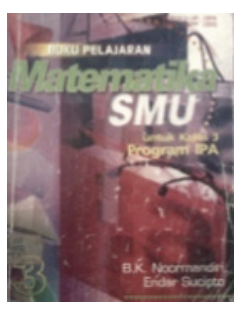

Judul: Buku Pelajaran Matematika SMU untuk Kelas 3 Program IPA

Pengarang: B.K. Noormandiri dan Endar Sucipto.

Penerbit: Erlangga, 2000

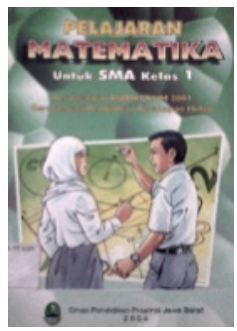

Judul: Pelajaran Matematika untuk SMA Kelas 1 (Berdasarkan Kurikulum 2004 Berorientasi Pendidikan Kecakapan Hidup)

Pengarang: Agus Rustiadin M., dkk.

Penerbit: Dinas Pendidikan Provinsi Jawa Barat, 2004 


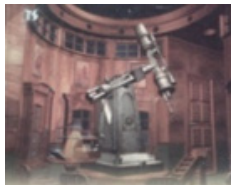

MATEMATIKA INOVATIF

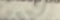

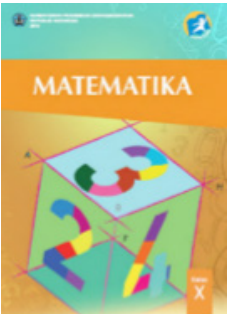

Judul: Matematika Inovatif (Konsep dan Aplikasinya) untuk Kelas X SMA dan MA

Pengarang: Siswanto

Penerbit: PT Tiga Serangkai Pustaka Mandiri, Solo, 2006

Judul: Matematika Kelas X

Pengarang: TIM

Penerbit: Kemdikbud Republik Indonesia

Tahun: 2013

Buku 1, Buku 2, Buku 3 dan Buku 4 secara berturut-turut merupakan salah satu buku yang digunakan sebagai buku pegangan guru pada tahun 2000, tahun 2004 (KBK), tahun 2006 (KTSP), dan tahun 2013 (Kurikulum 2013).

Pada Buku 1, materi dimensi tiga diberikan di kelas 3 SMU pada bab terakhir caturwulan 2. Urutan materi dimensi tiga pada buku tersebut dimulai dari irisan bangun ruang, garis tegak lurus bidang, jarak, proyeksi garis pada bidang, dan materi terakhir adalah tentang sudut. Apabila kita perhatikan, pada Kurikulum 1994 suplemen 1999, materi proyeksi diberikan setelah materi jarak. Artinya pada saat mempelajari konsep jarak pada bangun ruang tidak menggunakan konsep proyeksi. Hal ini mengakibatkan pada beberapa contoh soal yang disajikan masih memberikan contoh-contoh soal yang sederhana dan cenderung tidak mengaplikasikan konsep proyeksi dalam menyelesaikannya.

Permasalahan yang diberikan mengenai konsep jarak masih dapat diselesaikan tanpa menggunakan konsep proyeksi titik atau proyeksi garis baik pada garis ataupun pada bidang dalam bangun ruang. Sehingga wajar saja apabila materi proyeksi diberikan setelah materi jarak pada bangun ruang. Namun, di sisi lain peneliti melihat bahwa latihan soal mengenai konsep jarak yang diberikan kepada siswa dalam buku ini justru tidak sesederhana contoh yang diberikan. Untuk menyelesaikan permasalahan yang diberikan sebagai latihan, siswa dituntut untuk menguasai konsep proyeksi terlebih dahulu. Padahal, pada kenyataannya materi proyeksi diberikan setelah materi jarak diberikan, sehingga dimungkinkan siswa banyak mengalami kesulitan dalam menyelesaikan permasalahan-permasalahan tersebut.

Pada Buku 2, materi proyeksi tidak dibahas sama sekali. Konsep proyeksi tidak digunakan dalam menentukan jarak dari titik ke garis, atau jarak dari titik ke bidang, dan lainnya. Materi jarak pada dimensi tiga yang dibahas meliputi: (1) Jarak titik ke garis; (2) Jarak titik ke bidang; (3) Jarak antara dua garis sejajar; (4) Jarak antara dua garis bersilangan; dan (5) Jarak antara dua bidang sejajar

Sebagai contoh peneliti akan coba mendeskripsikan materi pada Buku 2 mengenai konsep jarak dari titik ke garis berikut ini: 
Jarak titik ke garis

Jarak titik $P$ ke garis $g$ dapat dilukis dengan langkah sebagai berikut:

a. Lukis bidang yang memuat titik $P$ sekaligus garis $g$

b. Lukis sebuah garis yang melalui titik $P$ dan memotong tegak lurus pada garis $g$ di $Q$.

c. $P Q$ adalah jarak titik $P$ ke garis $g$.

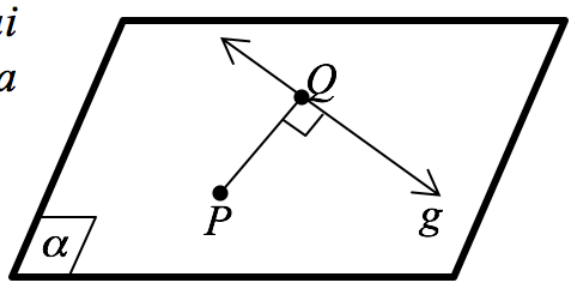

Pada materi tersebut, konsep proyeksi tidak diperkenalkan sama sekali kepada siswa, padahal konsep proyeksi titik terhadap garis menjadi salah satu letak kesulitan siswa dalam mencari jarak pada dimensi tiga.

Pada Buku 3, sebelum siswa membahas materi tentang jarak pada dimensi tiga, siswa terlebih dahulu diarahkan untuk membahas konsep proyeksi titik terhadap bidang. Namun, konsep proyeksi yang dijelaskan pada Buku 3 hanya sebatas penjelasan secara teoritis saja. Siswa diperkenalkan dengan berbagai istilah seperti titik hasil proyeksi, proyektor, dan bidang proyeksi. Ketika siswa hanya diperkenalkan dengan konsep proyeksi secara teoritis saja, kemungkinan besar pemahaman siswa terhadap konsep proyeksi tersebut kurang optimal.

Pada Buku 4, konsep proyeksi titik terhadap garis disajikan melalui permasalahan seharihari. Siswa dihadapkan pada masalah bagaimana cara mengukur jarak antara titik penalti pada lapangan sepak bola terhadap garis gawang. Permasalahan secara lengkap disajikan berikut ini.

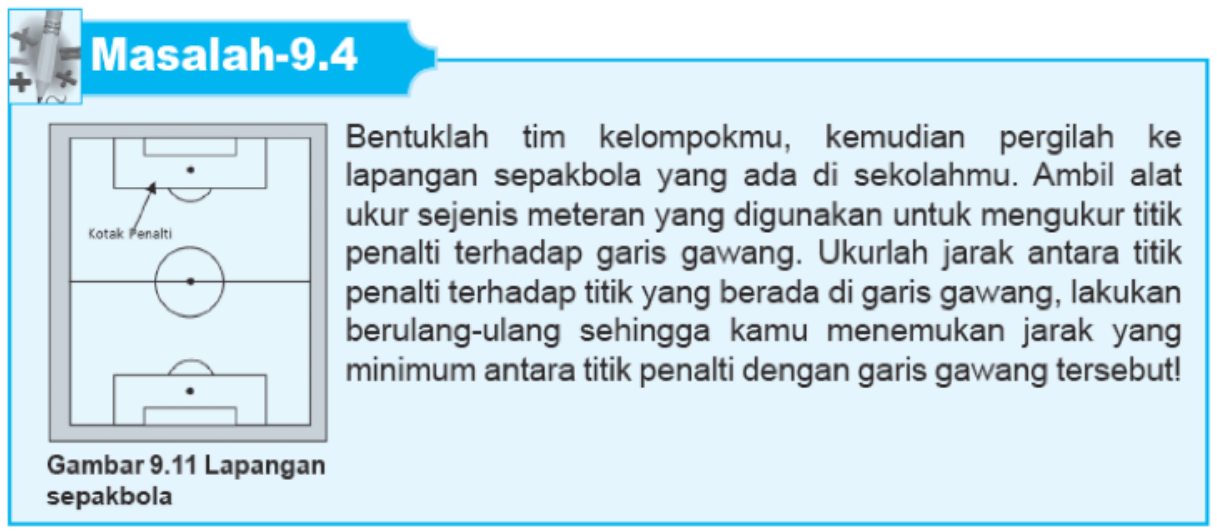




\section{Alternatif Penyelesaian}

Jika dimisalkan titik penalti adalah titik $P$ dan garis gawang merupakan garis lurus $I$. Tentukanlah beberapa titik yang akan diukur, misalkan titik-titik tersebut adalah $A, B, C, D$, dan $E$. Kemudian ambil alat ukur sehingga kamu peroleh jarak antara titik $P$ dengan kelima titik tersebut. Isilah hasil pengukuran kamu pada tabel yang tersedia.

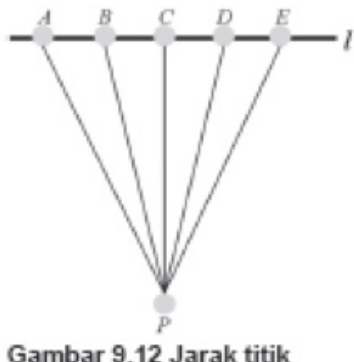

Tabel 8.1 Jarak Titik Penalti

\begin{tabular}{|c|c|}
\hline Titik & Jarak \\
\hline$P$ dan $A$ & \\
\hline$P$ dan $B$ & \\
\hline$P$ dan $C$ & \\
\hline$P$ dan $D$ & \\
\hline$P$ dan $E$ & \\
\hline
\end{tabular}

Apakah panjang ruas garis $P A, P B, P C, P D$, $P E$, adalah sama? Menurutmu, bagaimana menentukan jarak dari titik $P$ ke garis $l$ ? Apa yang dapat kamu simpulkan?

Sekarang, coba kamu bayangkan ada cahaya yang menyinari titik $P$ tepat di atasnya. Tentu saja akan diperoleh bayangan titik $P$ pada garis, yaitu $P^{\prime}$. Untuk itu kita dapat mengatakan bahwa panjang $P P^{\prime}$ merupakan jarak titik $P$ ke

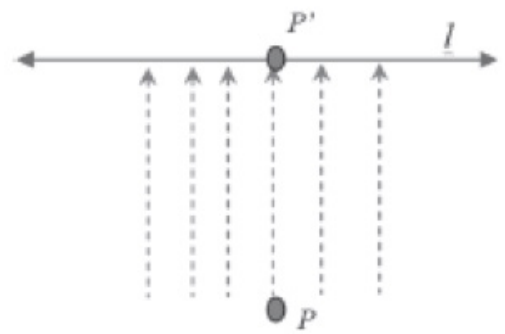

Gambar 9.13 Proyeksi titik $P$ pada garis I garis $l$. Sedangkan, $P^{\prime}$ merupakan projeksi titik $P$ pada garis $l$. Jadi, jarak titik $p$ ke garis 1 adalah $P P^{\prime \prime}$.

Sumber: Buku Matematika Kelas X, Kemdikbud, 2013

Materi pada Buku 4 yang diuraikan di atas, memberikan penjelasan yang lebih lengkap mengenai konsep proyeksi titik pada garis apabila dibandingkan dengan materi pada Buku 1, Buku 2 dan Buku 3. Namun, pada Buku 4, proses aksi siswa dalam memahami konsep proyeksi tersebut masih terbilang kurang optimal. Siswa secara umum mampu dengan memahami konsep proyeksi seperti yang disajikan pada Buku 4, tetapi ketika siswa dihadapkan pada permasalahan secara langsung yang melibatkan konsep proyeksi titik pada garis dalam bangun ruang, siswa masih mengalami kesulitan. Hal ini mungkin disebabkan oleh minimnya pengalaman belajar siswa (proses aksi) dalam mengkaji konsep proyeksi tersebut. Ditambah lagi, keterbatasan imajinasi siswa dalam membayangkan hasil proyeksi titik pada garis. Untuk menggali jawaban dari permasalahan tersebut, peneliti mencoba melakukan wawancara kepada salah seorang guru kelas X SMA di Kota Tasikmalaya dengan tujuan untuk menggali informasi mengenai hambatan belajar yang dialami siswa dalam mempelajari materi dimensi tiga, khususnya tentang konsep jarak pada bangun ruang. Berdasarkan hasil wawancara tersebut, diperoleh informasi bahwa kesulitan yang paling banyak di temukan guru dalam mengajarkan konsep jarak, yaitu siswa belum optimal dalam menentukan proyeksi titik baik pada garis maupun pada bidang. Hal yang paling mengejutkan dari hasil wawancara tersebut adalah ternyata bukan hanya siswa yang merasa kesulitan dalam mempelajari konsep jarak, bahkan gurunya sendiri mengalami hal yang sama dalam mengajarkan cara menentukan proyeksi titik pada garis dan pada bidang dalam dimensi tiga. Guru merasa kesulitan untuk mengomunikasikan apa yang dia lihat dalam pikirannya sebagai hasil dari visualisasi yang dia lakukan kepada siswa. Untuk membantu visualisasi siswa, terkadang guru menggunakan alat peraga berupa rangka kubus, balok, limas, dan prisma sebagai alat untuk membantu proses visualisasi siswa. Namun, pada saat guru akan melakukan manipulasi benda-benda tersebut disesuaikan dengan persoalan yang dihadapi, 
guru mengalami kendala. Dengan demikian, peneliti beranggapan bahwa penggunaan software geometri seperti sangat diperlukan untuk membatu siswa dalam memperkaya pengalaman belajarnya, sekaligus software geometri juga akan membantu proses aksi dalam pembelajaran. Setelah siswa dihadapkan pada berbagai permasalahan mengenai proyeksi titik terhadap garis berbantuan software Cabri 3D, siswa diharapkan mampu melakukan generalisasi atau abstraksi atau menemukan sebuah kesimpulan dari proses aksi yang telah di lakukan sebelumnya (proses formulasi). Baru dari sini, siswa dapat melakukan proses validasi di mana siswa mampu membuktikan kebenaran dari sebuah klaim atau memberikan klarifikasi terhadap kesimpulan yang telah diperolehnya (mengapa kesimpulannya seperti itu?). Setelah semua proses itu dilalui, barulah siswa menerapkan konsep yang telah diperolehnya pada beberapa konteks atau permasalahan (proses institusionalisasi).

Berdasarkan hasil pengamatan peneliti terhadap beberapa buku teks (buku pegangan guru) yang digunakan oleh guru sejak Kurikulum 2004 (KBK), Kurikulum 2006 (KTSP), dan Kurikulum 2013, secara garis besar memiliki kesamaan. Alur pembelajaran konsep jarak titik ke garis dan titik ke bidang pada buku teks sebelumnya adalah sebagai berikut:

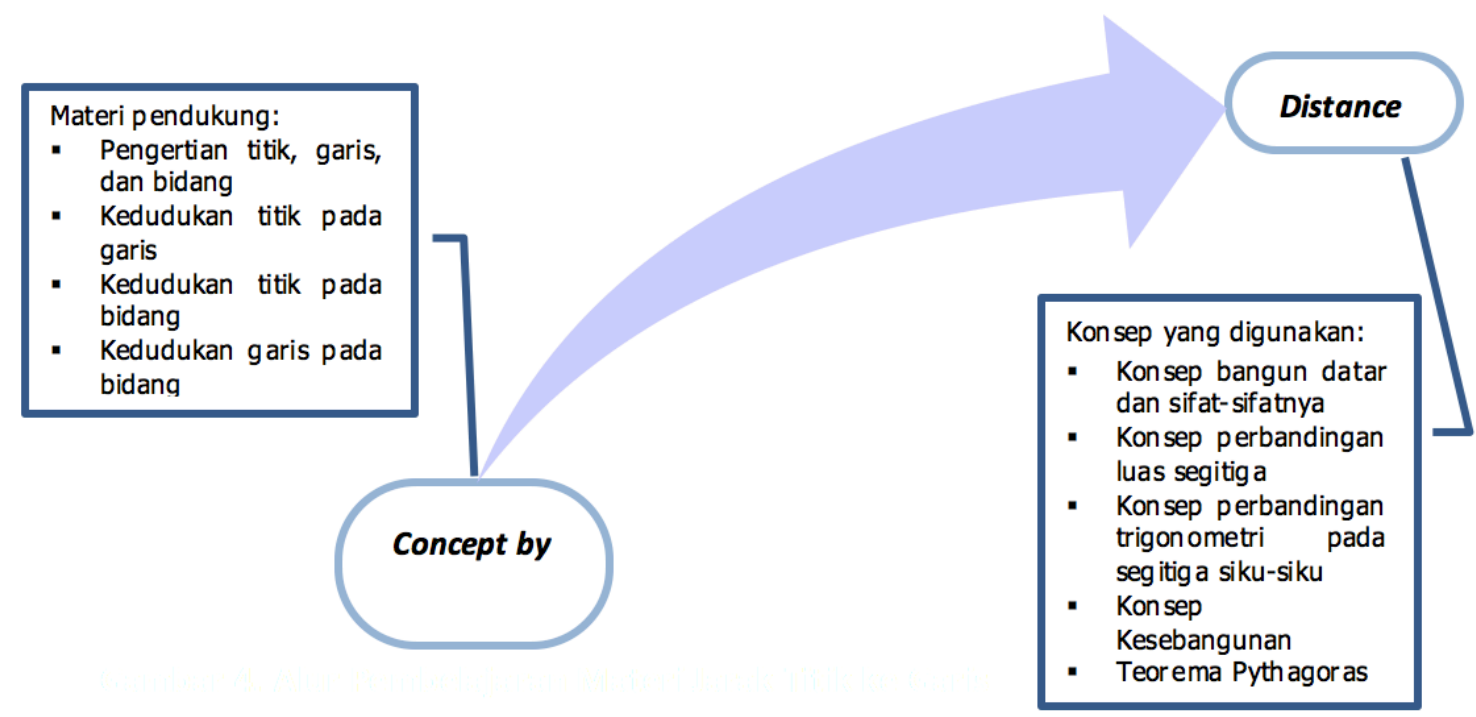

Gambar 4 Alur Pembelajaran Materi Jarak Titik ke Garis dan Jarak Titik ke Bidang pada Buku Teks

Berdasarkan alur pembelajaran materi jarak dalam dimensi tiga yang disajikan pada Gambar 4 , ternyata terdapat loncatan konsep yang cukup jauh. Antara titik awal dan akhirnya. Di awal pembelajaran siswa diperkenalkan dengan konsep jarak titik terhadap garis atau jarak titik terhadap bidang secara teoritis (concept by definition) dan setelah tahapan ini selesai dilakukan, guru langsung memberi soal untuk mencari jarak dari titik ke garis dan jarak dari titik ke bidang yang disajikan langsung pada bangun ruang. Tentu saja alur pembelajaran seperti ini akan menyulitkan siswa dalam memahami konsep jarak ini. Oleh karena itu, berdasarkan kajian terhadap learning obstacle siswa pada materi jarak antara titik dengan garis, peneliti mencoba untuk menyusun Hypothetical Learning Trajectory (HLT) seperti disajikan pada Gambar 5. 


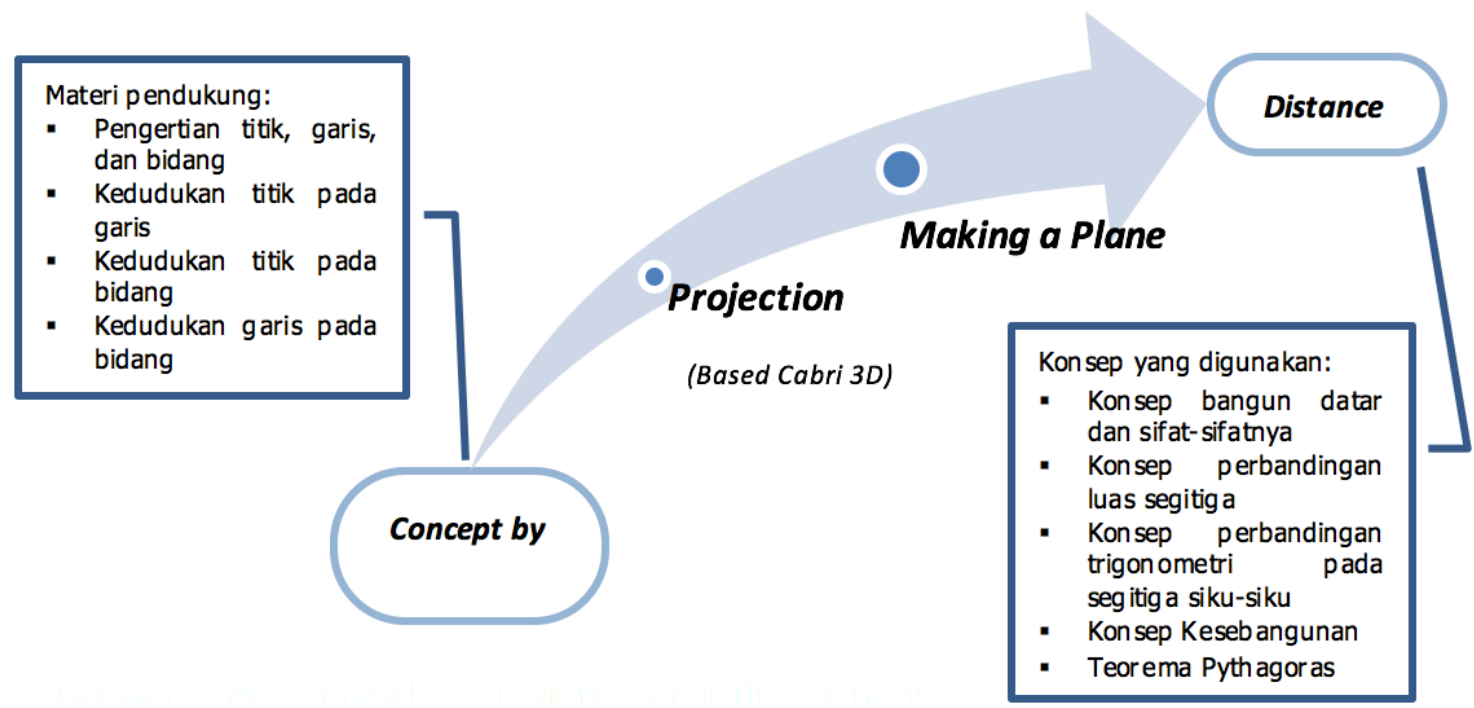

Gambar 5 menunjukkan bahwa setelah siswa memahami konsep jarak dari titik ke garis melalui permasalahan-permasalahan yang berada di sekitar siswa, siswa diarahkan untuk memahami konsep jarak dari titik ke garis. Selanjutnya siswa dilatih menemukan titik proyeksi melalui pengamatan menggunakan software Cabri 3D. Pada tahap ini penggunaan software Cabri 3D sangatlah perlu untuk mempercepat proses aksi dalam pembelajaran. Di samping itu, dengan menggunakan software Cabri 3D siswa dapat melakukan penyelidikan untuk mengidentifikasi bentuk bidang yang akan terbentuk (making a plane). Barulah siswa dapat masuk pada tahap akhir yaitu menghitung jarak dari titik ke garis dengan menggunakan berbagai konsep sesuai dengan jenis bidang yang terbentuk.

Hypothetical Learning Trajectory (HLT) pembelajaran materi jarak antara titik dengan bidang, disajikan pada Gambar 6 berikut ini.

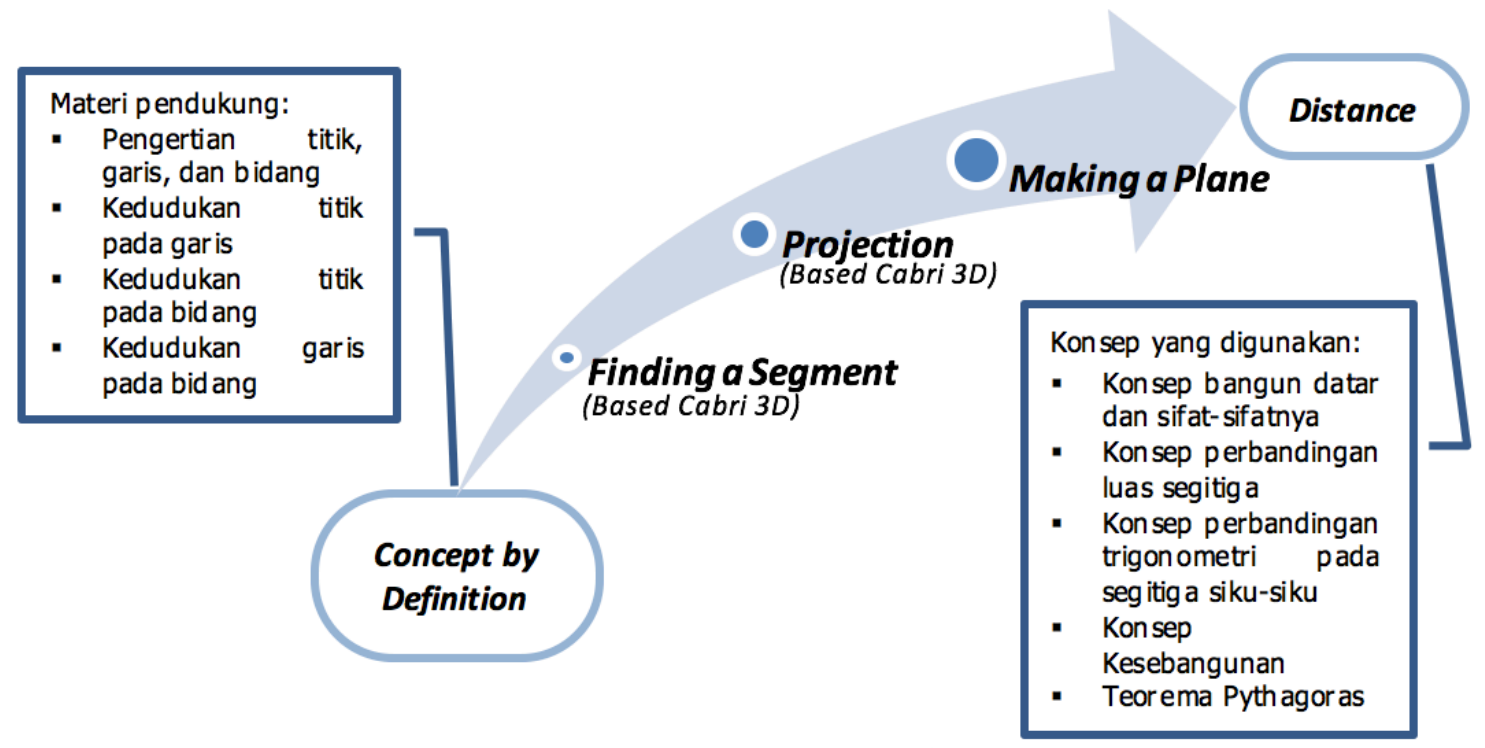

Berdasarkan Gambar 6 di atas, peneliti menyusun HLT pembelajaran materi jarak titik ke bidang. Tidak jauh berbeda dengan pembelajaran materi jarak dari titik ke garis, pada materi ini pun pembelajaran diawali dengan memperkenalkan siswa dengan permasalahan- 
permasalahan yang berhubungan dengan konsep jarak dari titik ke bidang. Selanjutnya, dengan menggunakan software Cabri 3D, siswa diarahkan untuk menyelidiki dan melakukan pengamatan dalam menemukan ruas garis pada bidang (finding a segment) yang memuat proyeksi suatu titik pada bidang tersebut (projection). Setelah itu, siswa diarahkan pada tahap selanjutnya yaitu membuat sebuah bidang yang memuat titik dan ruas garis yang ditemukan pada tahap sebelumnya, dan diakhiri dengan menghitung jarak dari titik ke bidang dengan menggunakan berbagai konsep yang sesuai.

\section{SIMPULAN DAN SARAN}

Berdasarkan hasil dan pembahasan yang telah diuraikan sebelumnya, dalam pembelajaran materi dimensi tiga, khususnya tentang konsep jarak dari titik ke garis dan dari titik ke bidang, hasil pengamatan peneliti tentang learning obstacle yang dialami siswa ditinjau dari epistemological dan didactical obetacle terhadap 32 orang siswa terletak pada (1) Menentukan letak hasil proyeksi suatu titik terhadap garis, (2) Menentukan letak hasil proyeksi suatu titik terhadap bidang, dan (3) Membuat dan mengenali bentuk sebuah bidang yang memuat titik dan memuat ruas garis pada bidang tersebut (yang memuat hasil proyeksi titik).

Hasil pengamatan peneliti terhadap beberapa buku teks (buku pegangan guru) yang digunakan oleh guru secara garis besar memiliki kesamaan alur pembelajaran. Alur pembelajaran konsep jarak titik ke garis dan titik ke bidang pada beberapa buku teks sebelumnya adalah mulai dari concept by definition langsung menyelesaikan persoalan jarak (distance). Berdasarkan alur pembelajaran tersebut, ternyata terdapat loncatan konsep yang cukup jauh. Tentu saja alur pembelajaran seperti ini akan menyulitkan siswa dalam memahami konsep jarak. Oleh karena itu, perlu disusun Hypothetical Learning Trajectory (HLT) yang memperhatikan learning obstacle siswa pada materi jarak, agar siswa mampu memahami konsep jarak pada dimensi tiga secara lebih optimal. HLT pada pembelajaran materi jarak antara titik dengan garis meliputi: concept by definition, projection, making a plane, dan distance, sedangkan untuk HLT pada pembelajaran materi jarak antara titik dengan bidang meliputi: concept by definition, finding a segment, projection, making a plane, dan distance.

Dalam penelitian ini, peneliti belum melakukan uji coba secara mendalam tentang HLT. Oleh karena itu disarankan kepada peneliti selanjutnya untuk menguji coba secara terbatas dan luas serta mengimplementasikan HLT yang peneliti susun dalam pembelajaran materi jarak pada bangun ruang, terutama dalam penyusunan desain didaktis agar hambatan belajar yang dialami siswa dapat diminimalisir, sehingga pemahaman siswa dalam mempelajari materi dimensi tiga dapat lebih optimal.

\section{DAFTAR RUJUKAN}

Brosseau, G. (1997). Theory of Didactical Situations in Mathematics. New York, NY: Kluwer Academic Publishers.

Clements, D. H., \& Sarama, J. (2004). Learning trajectories in mathematics education. Mathematical thinking and learning, 6(2), 81-89.

Jiang, Z. (2008). Explorations and Reasoning in the Dynamic Geometry Environment. Retrieved from http://atcm.mathandtech.org/EP2008/ papers_full/2412008_15336.pdf. 
Kementerian Pendidikan dan Kebudayaan. (2013). Matematika Kelas X. Jakarta, Indonesia: Author.

Moleong, L. J. (2012). Metodologi Penelitian Kualitatif. Bandung, Indonesia: Remaja Rosdakarya.

Negoro, \& Harahap, B. (2010). Ensiklopedia Matematika. Bogor, Indonesia: Ghalia Indonesia.

Noormandiri, B. K., \& Sucipto, E. (2000). Buku Pelajaran Matematika SMU untuk Kelas 3 Program IPA. Jakarta, Indonesia: Erlangga.

Ruseffendi. (2010). Dasar-dasar Penelitian Pendidikan dan Bidang non-Eksakta Lainnya. Bandung, Indonesia: Tarsito.

Rustiadin M., \& Agus. (2004). Pelajaran Matematika untuk SMA Kelas 1 (Berdasarkan Kurikulum 2004 Berorientasi Pendidikan Kecakapan Hidup). Indonesia: Dinas Pendidikan Provinsi Jawa Barat.

Siswanto. (2006). Matematika Inovatif (Konsep dan Aplikasinya) untuk Kelas X SMA dan MA. Solo, Indonesia: Tiga Serangkai Pustaka Mandiri.

Suryadi, D. (2005). Pengembangan Bahan Ajar dan Kerangka-Kerja Pedagogis Matematika untuk Menumbuhkembangkan Kemampuan Berpikir Matematika Tingkat Tinggi Siswa SMP. [Laporan Penelitian]. Universitas Pendidikan Indonesia.

Suryadi, D., et al. (2010). Model Antisipasi dan Situasi Didaktis pada Pembelajaran Matematika Kombinatorik Berbasis Pendekatan Tidak Langsung. Retrieved from http://file. upi.edu/Direktori/FPMIPA/JUR._PEND._MATEMATIKA/195802011984031-DIDI_ SURYADI/ DIDI-24.pdf.

Suryadi, D. (2015). Desain Didaktis Pengenalan Bilangan Bulat: Kreasi Guru-Guru Sekolah Dasar Gagasceria Bandung ditinjau dari Perspektif DDR. Prosiding Seminar Nasional Pendidikan Matematika Universitas Siliwangi, 18 Oktober 2015. Tasikmalaya, Indonesia: FKIP Universitas Siliwangi.

Van de Walle, J.A. (2008). Matematika Pengembangan dan Pengajaran Jilid 2 (Suyono, Trans.). Jakarta, Indonesia: Erlangga.

Wahyudin. (2013). Matematika Dasar Pengetahuan Bermuatan Pedagogis (Gagasan-gagasan yang Kuat untuk Para Guru). Bandung, Indonesia: Mandiri. 